\section{A CASE OF}

SYPHILIS, AND SOME OF ITS EFFECTS. TWO CASES OF INFECTION THROUGH THA NTETUS, AND LOCOMOTOR ATAXY.

BY THOMPSON FORSTER, M.R.C.S., L.S.A., FORMERLY HOUSE-SURGEON TO THE MANCHESTER ROYAL INFIRMARY.

L. J. F_—, a dark, phlegmatic, temperate man, aged thirty, of gentle disposition, fair intellectual power, and highly moral, excepting for a short time, sought advice in September, 1862. He had a small hard chancre, which was followed by enlarged hard glands in the groin. He remained in this condition for some weeks, when the glands gradually resumed their normal condition. In January, 1863, he suffered from slight sore-throat. The local treatment consisted in the application of nitrate of silver; mercury and iodide of potassium were prescribed, which were continued for four months, long after all symptoms of the disease had disappeared. From 1863 until the spring of 1882 he had no symptoms of syphilis. In January, 1865, he married a very healthy, strong girl. In April she had sores on the vulva, aborted in May, had ulcerated sore-throat, and was covered with a copper scaly rash. In May, 1866, a seven months' child was born, with dry wrinkled skin, and soon after had sore mouth, coppery rash, rough skin, snuffles, \&c., and died in ten weeks. The mother gradually acquired, and continued to have, fair health, until May, 1868, being then pregnant, when she was suddenly seized with difficalty of breathing, and died before any medical aid could be obtained.

In May, 1872, L. J. F married again. His second wife was also a very healthy girl. She became pregnant in June, suffering from copper rash, debility, loss of flesh, and miscarried in November. The child lived a few hours only, was shrivelled, small, and apparently diseased. The mother recovered slowly, but did not become pregnant for some years. After consultation, although the opinions were opposed to it, I put her under a course of mercury and iodide of potassium in 1876, as well as her husband, for over two months. They both regained good health. In 1877 she became pregnant a second time, and in July, 1878, a healthy eight months' child was born. In January, 1879, she again became pregnant, a healthy child being born at full time in March, 1880. In January, 1881, L. J. Fhad a fall, the effects of which he felt for a time, and then they passed off. In the spring he began to show symptoms of locomotor ataxy; in the following winter numbness of the end of the thumb and finger, hesitation in speech, slow walk, loss of knee action, \&c., were well marked. The symptoms rapidly increased in intensity, and he died in the autumn, after having suffered very severely from delusions. It was very difficult to make his immediate friends understand the gravity of the case. At a consultation in the spring the prognosis was rapid increase of disease and probable death.

Remarks.-I think this case worth recording from the length of time it was under observation and the many interesting points exhibited-namely, the effects of the mercury and iodide of potassium ; the infection through foetus in both cases, though modified in the second; the caution necessary in giving an opinion as to marriage after syphilitic infection; the curious way that L. J. F- remained healthy personally as far as could be seen for the long period, yet infecting two others at different periods ; his attack of locomotor ataxy and death, in spite of free treatment with mercury and iodide of potassium. During the case two physicians and one surgeon, very eminent in London, were consulted.

\section{A NEW METHOD OF TREATING SPRAINS By THOS. L. SHEARER, M.B., C.M. EdIN.}

EVERYONE who has had sprains to treat in practice must have been at times annoyed by the slowness of recovery of the injured part. This is not so important in hospital patients, many of whom, enjoying the life diet \&c. of these institutions, do not object to prolonged treatment; but in the wealthier classes in private practice the surgeon must often hear complaints that the injury is so long in recovering. I have had a considerable number of sprained limbs to treat, and, after employing the usual plans of treatment, was led to adopt a new agent-clay. The clay is simply that used for making briclas, free sum gravel, dried, and finely pulverised in a mortar. The pondarod clay is mixed with water so as to form a thick and moist comointance. This is apread on muslin to the depth of a quarter of an mus, and applied entirely around the part. Over this is placed a rubber roller bandage, just lightly enough to keep the dressing from shifting and to retain the moisture. At the end of twenty-four or thirty-six hours the dressing must be renewed. It may be well to relate a few cases by way of illustration.

CASE 1.-Mr. T- aged fifty-eight, was thrown from his carriage, and in addition to other injuries, received a severe sprain of his ankle, completely incapacitating him from motion of any kind. The part was hard, swollev, intensely painful, and throbbing. The dressing, as above described, was applied, and in twenty-four hours the pain was almost entirely gone, and the swelling to a great degree had subsided. The dressing was renewed daily, and in eight days the patient was going about attending to his business. The part was free from pain and natural in every respect.

CASE 2.-Mr. McC_-, aged sixty, slipped and sprained his ankle so severely as to confine him to bed. The treatment was the same as that employed in Case 1, and the patient was out and walking in the streets in ten days.

CASE 3.-Mrs. A-, aged seventy-four, in stepping from her carriage missed her footing, and twisted her left knee violently. In a few hours the part was greatly swollen, hot, throbbing, and painful ; the least motion of the joint caused excruciating agony. Pressure over the ligament was especially painful. Next day I saw the patient, and applied the clay dressing. The day after the patient was much easier, the swelling rapidly subsiding. The pain was almost nil, and movement of the part was not followed by such distress. The lady was walking in her house in ten days after the injury.

Dr. Hewson, of Philadelphia, about ten years ago introduced earth as a means of treating fibroid tumours of the uterus, and also sprinkled burns with the dry earth, claiming that the tendency to deformity in the latter cases was lessened. However, I am not aware of sprains being previously dressed with clay, and it was thought as well to lay the efficacy of the method before the profession. A number of other cases could be cited, but they would simply be a repetition of those already mentioned. While speaking of clay, it would, perhaps, not be amiss to state that the powdered dried earth sprinkled on the surface of an ulcer, and adhesive straps applied over it, is a capital dressing for cases which are so weak that even the weakest ointments tend to break down the granulations.

Baltimore, U.S.

\section{9 ettirtor}

\section{HOSPITAL PRACTICE, BRITISH AND FOREIGN.}

Nulla antem estalia pro certo noscendivia, nisi quamplurimas et morborum ot disectionum historias, tum aliornm tum proprias collectas habere, et Inter se comparare.-Morga Gri De Sed. et Caus. Morb., lib. iv. Procomium.

\section{ST. THOMAS'S HOSPITAL.}

BONY ANCHYLOSIS OF LOWER JAW ; REMOYAL OF A WEDGESHAPED PIECE OF BONE ON EACH SIDE; RECOVERY, WITH GOOD MOVEMENT OF JAW.

(Under the care of Mr. SYDney Jones.)

For the following notes we are indebted to Mr. W. H. Battle, surgical registrar.

T. A. H-, aged eighteen, was admitted on Nov. 22nd, 1883. Family history and previous history good. When between two and three years of age patient fell from a window on to a stone pyramid. The medical man called in did not say for certain whether the jaw was broken or not, but treated the case as if it had been a fracture. When the bandages were removed it was found that the lower jaw was fixed and the patient was unable to open his mouth; there was, however, a small interval between the teeth in front, and this, it would seem, was maintained by corks in the course 